\title{
Redbay Ambrosia Beetle-Laurel Wilt Pathogen: A Potential Major Problem for the Florida Avocado Industry 1
}

Jonathan H. Crane, Jorgé Peña, and J.L. Osborne ${ }^{2}$

\section{Descriptions}

\section{Ambrosia Beetles}

Ambrosia beetles are members of the insect tribe Xyleborini and are known for attacking various woody plants, causing some limb and stem dieback and sometimes plant death (Rabaglia et al., 2006; Atkinson and Peck, 1994). There are at least 30 species of ambrosia beetles in Florida, several of which are non-native (Thomas, 2007). Typically ambrosia beetles have a symbiotic relationship with a fungus, and the beetles carry fungal spores on their bodies.

When the beetles bore into the sapwood of the host tree, the galleries formed from the beetle boring are inoculated with the fungal spores, which then germinate and infect the host tissue (Atkinson and Peck, 1994; Thomas, 2007). The fungus continues to grow in the galleries and adjacent sapwood, disrupting the flow of water and nutrients in the tree. The fungus grows on the living wood of the tree, and the redbay ambrosia beetle adults and larvae feed on the fungus. Of the many ambrosia beetle species in Florida, several Xylosandrus species attack avocado trees, but their boring and their associated fungi do not generally cause the entire tree to die (Atkinson and Peck, 1994; Bryant, 2007; Mayfield, 2007; Mayfield and Thomas, 2006). In contrast, the redbay ambrosia beetle and its associated fungus (which causes laurel wilt; Raffaelea lauricola) can cause whole tree death (Fraedrich et al., 2008).

Most ambrosia beetles attack trees and shrubs that are stressed, dying, or dead. Plant stress may be the result of drought, flooding, freezing temperature damage, wind damage, or very poor cultural practices. In contrast, some ambrosia beetles -- the redbay ambrosia beetle included -- attack healthy trees. More importantly, the fungus that causes laurel wilt, which accompanies this beetle, often causes tree death.

1. This document is HS1136, one of a series of the Horticultural Sciences Department, Florida Cooperative Extension Service, Institute of Food and Agricultural Sciences, University of Florida. Original publication date, February 2008. Revised December 2008. Visit the EDIS Web site at http://edis.ifas.ufl.edu.

2. J. H. Crane, professor, Horticultural Sciences Department, and Tropical Fruit Crops Extension Specialist, Tropical Research and Education Center (TREC) -- Homestead, FL; J.E. Peña, professor, Entomology and Nematology Department, and Tropical Fruit Entomologist, TREC -- Homestead, FL; and J.L. Osborne, Multi-county Tropical Fruit Crops Agent, Miami-Dade County Extension Service, Homestead, FL, Cooperative Extension Service, Institute of Food and Agricultural Sciences, University of Florida, Gainesville, FL.

The Institute of Food and Agricultural Sciences (IFAS) is an Equal Opportunity Institution authorized to provide research, educational information and other services only to individuals and institutions that function with non-discrimination with respect to race, creed, color, religion, age, disability, sex, sexual orientation, marital status, national origin, political opinions or affiliations. U.S. Department of Agriculture, Cooperative Extension Service, University of Florida, IFAS, Florida A. \& M. University Cooperative Extension Program, and Boards of County Commissioners Cooperating. Larry Arrington, Dean 


\section{Redbay Ambrosia Beetle}

The redbay ambrosia beetle (Xyleborus glabratus) is a very small (about $2 \mathrm{~mm}$ in length), dark brown to black, cylinder-shaped beetle, similar to other ambrosia beetles found in Florida (Hanula et al., 2008) (Figure 1). The male beetles are smaller than the females and cannot fly. In contrast, the females are strong flyers. Like other ambrosia beetles, redbay ambrosia beetles bore into the wood just below the bark, form galleries in the sapwood, and inoculate these galleries with spores of the fungus they carry (Raffaelea lauricola). The fungus feeds on the sapwood, and then the adult and larval redbay ambrosia beetles feed on the fungus.

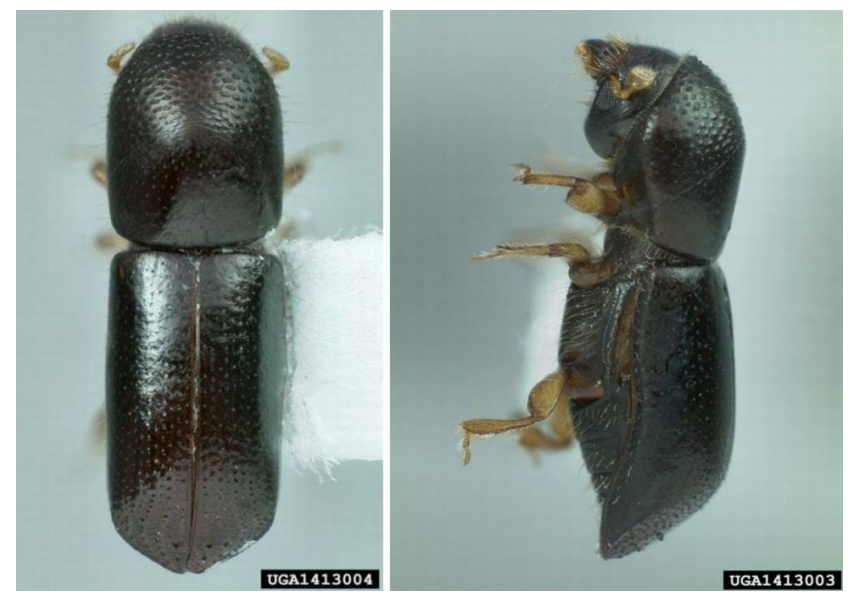

Figure 1. Redbay ambrosia beetles (Xyleborus glabratus): a) top view and b) side view of an adult. Credits: Michael C. Thomas, Florida Department of Agriculture and Consumer Services

\section{Laurel Wilt Pathogen}

The adult female redbay ambrosia beetle carries in a special pouch in its mouth -- called a mycangia -the spores of the fungus that causes laurel wilt (Raffaelea lauricola) (Fraedrich et al., 2008; Harrington et al., 2008). As the beetle bores into the wood, forming galleries, the spores carried in its mycangia and on its body inoculate the tree, germinate and grow, colonizing the outer wood (sapwood) of the host plant (Figure 2). The fungal hyphae and colonized sapwood block the movement of water and nutrients in the tree.

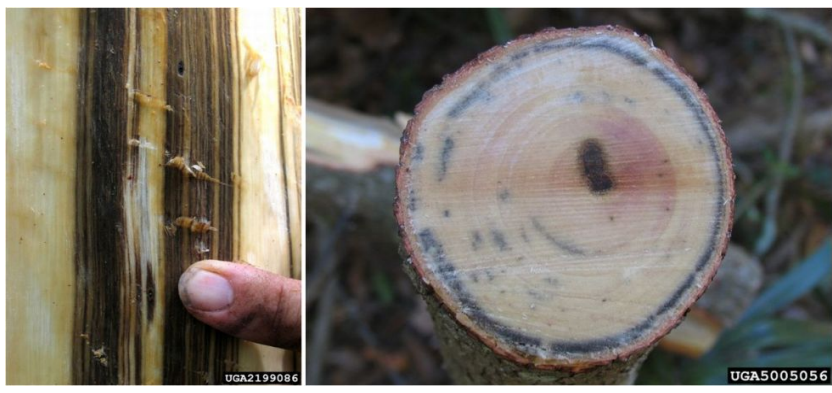

Figure 2. Symptoms of laurel wilt fungal (Raffaelea lauricola) colonization of redbay trees. a) Removing the bark reveals dark staining of the sapwood. b) The dark color of the outer ring of sapwood below the bark indicates the tree has been infested by the redbay ambrosia beetle and the wood has been colonized by the laurel wilt pathogen. The fungal hyphae, which have colonized sapwood, block movement of water and nutrients in the tree. Credits: Albert Mayfield, Florida Department of Agriculture and Consumer Services

\section{Origin, Detection, and Spread of the Pest}

The redbay ambrosia beetle is native to India, Japan, Myanmar, and Taiwan (Hanula et al., 2008; Mayfield and Thomas, 2006). However, the origin of the fungus that accompanies the beetle and causes laurel wilt is not known. The fungus is presumed to have been introduced with the beetle. The beetle and fungus are not known to be major pests in their native range. The beetle is believed to have been introduced into Georgia in 2002 by infested packing materials, such as wooden crates and pallets (Thomas, 2007).

This insect-fungal pest attacks a number of forest tree species in Asia, including Asian spicebush (Lindera latifolia), yellow litsea (Litsea elongata), and sal (Shorea robusta) (Rabaglia et al., 2006). However, we are not aware of any reports in Asia of this pest attacking avocado (Persea americana).

The redbay ambrosia beetle was first detected in a survey trap in Port Wentworth, Georgia, in 2002. By 2003 this beetle and its associated fungus had caused substantial destruction to the native redbay (Persea borbonia) in Georgia and in South Carolina (Bryant, 2007; Mayfield and Thomas, 2006) (Fig. 3). During the spring of 2005, this pest was detected on redbay in Duval County, Florida. 
Since then the pest has spread south from northeastern Florida (Duval County), along the east coast of Florida, to as far south as Indian River County in 2006, Brevard County in 2007, and Okeechobee and Oceola counties in 2008 (http://www.fs.fed.us/r8/foresthealth/laurelwilt/ dist_map.shtml) (Mayfield, 2007; Reid et al., 2008).

The range of redbay trees is from southern Delaware to coastal Virginia to eastern Texas and includes coastal areas of North Carolina and South Carolina, Georgia, southern Alabama, Mississippi, parts of Louisiana, and all of Florida (Gilman and Watson, 2006).

Avocado, a redbay relative and host of the redbay ambrosia beetle, is grown in home landscapes throughout Florida. Thus, the continuous range of redbay and avocado trees throughout Florida could facilitate the natural spread of the redbay ambrosia beetle and laurel wilt pathogen to the commercial avocado production area in Miami-Dade County, Florida.

\section{Plant Hosts in the United States}

In Asia and the United States, the redbay ambrosia beetle appears to be most attracted to woody plants in the Lauraceae (laurel) family although there are reports in Asia of the beetle attacking some plant species in Fabaceae, Fagacea, and Dipterocarpaceae (Fraedrich et al., 2008).

Florida has numerous species in the Lauraceae family; some of these are forest species, some of ornamental value, and one, avocado, is a major commercial fruit crop species (Mayfield et al., 2008c; Ploetz and Peña, 2007). At present, the Florida avocado industry covers about 7,400 acres and is estimated to be worth about $\$ 13$ million annually (Pollock and Perez, 2007).

In the southeastern United States, the reported hosts of the redbay ambrosia beetle/laurel wilt pathogen have included the redbay $(P$. borbonia), silk bay (P. borbonia var. humilis), swampbay $(P$. palustris), sassafras (Sassafras albidum), and avocado (P. americana) (Mayfield, 2007; Mayfield, 2008). The laurel wilt pathogen has also been recovered in the southeastern United States from diseased plants of pondberry (Lindera melissifolia), camphor tree (Cinnamomum camphora), and pondspice (Litsea aestivalis) trees.

Recent research in Florida has shown that avocado cultivars appear to vary in their susceptibility to the fungus that causes laurel wilt. Preliminary results to date suggest 'Brogdon', 'Miguel', 'Donnie', 'Simmonds', 'Lula', 'Bernecker', and 'Monroe' avocado trees were more susceptible to laurel wilt than the following: 'Reed', 'Choquette', 'Catalina', 'Florida Hass', 'Winter Mexican', 'Hass' and 'Hall' (R.C. Ploetz, unpublished data; Mayfield et al., 2008b).

However, in one trial, although 'Monroe', 'Winter Mexican', and 'Catalina' showed the discolored sapwood symptom of the laurel wilt pathogen, these trees did not succumb to the disease. Preliminary results also demonstrate larger trees appear to be more affected by the laurel wilt pathogen than younger trees. All Florida avocado varieties tested to date are attacked by the redbay ambrosia beetle.

\section{Additional Recent Research Findings}

1. The seasonal flight of the female redbay ambrosia beetle appears to be most active from June through October. However, when activity of the female redbay was monitored in Huntington Island, S.C., some movement was detected during late fall and winter (Hanula et al., 2008). Because that area has slightly cooler average-minimum temperatures from October through March than South Florida has during those same months, those findings may not reflect the behavior of the female redbay ambrosia beetle in South Florida's southeastern coastal areas.

2. Preliminary data suggest that the redbay ambrosia beetle does not produce an aggregation pheromone (an attractant) (Rabaglia et al., 2006; Hanula et al., 2008). Diseased bolts (pieces of wood) and, by implication, the fungus that causes laurel wilt do not attract the redbay ambrosia beetle. As a result, the galleries and frass of infested bolts do not appear to attract additional redbay ambrosia beetles. By contrast, 


\section{Distribution of Counties with Laurel Wilt Disease* Symptoms, by Year of Initial Detection}

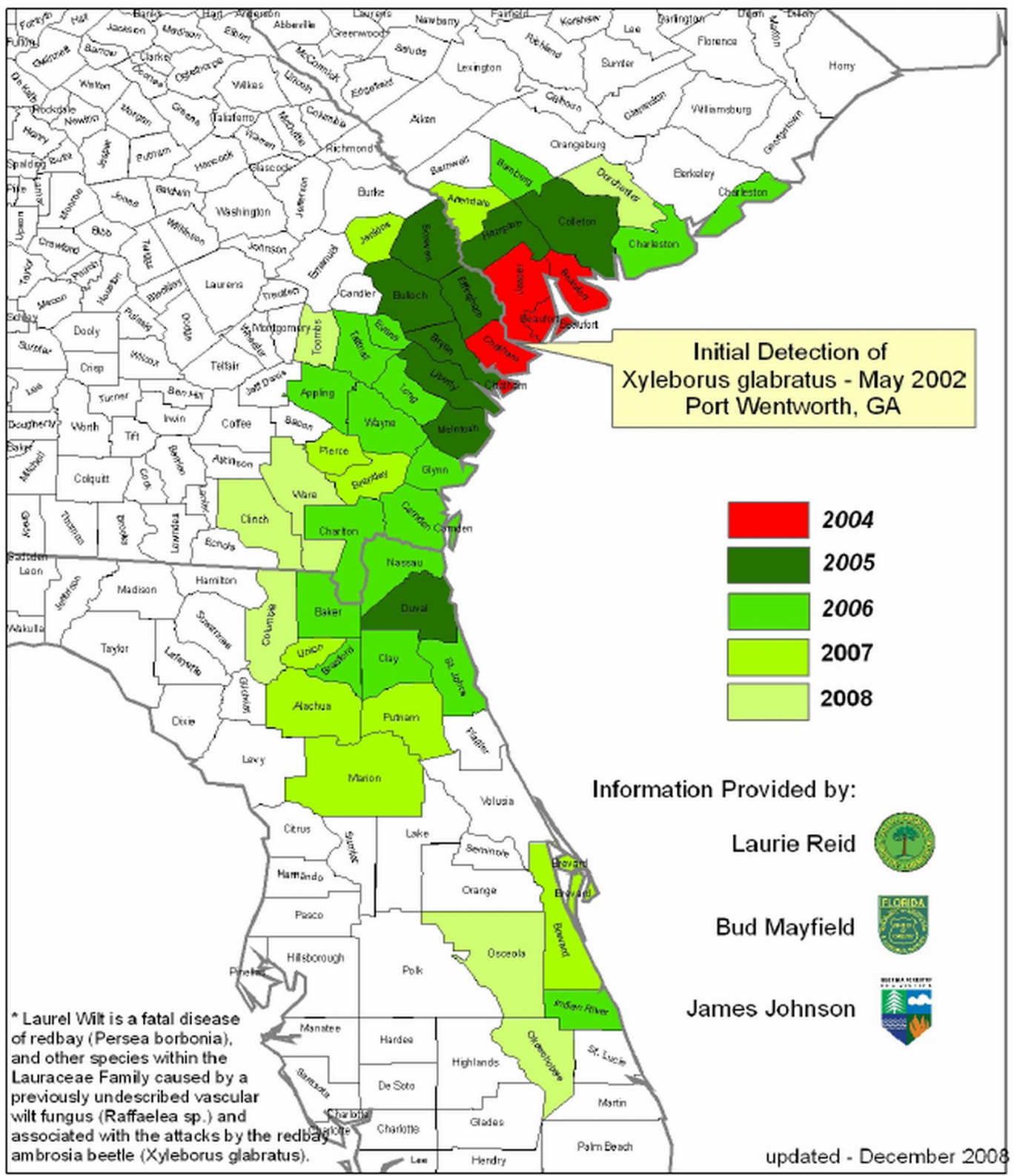

Figure 3. Map showing the spread of the redbay ambrosia beetle in the southeastern United States and in Florida in particular. Note that several Florida counties north of Indian River County were not infested in 2006, indicating that the beetle was moved to Indian River County in contaminated wood products (most likely firewood). Credits: Laurie Reid, South Carolina Forestry Commission; Albert Mayfield, Florida Department of Agriculture and Consumer Services, and James Johnson, Georgia Forestry Commission -- http://www.fs.fed.us/r8/foresthealth/laurelwilt/dist_map.shtml

data and observations from other ambrosia beetle species suggest those other ambrosia beetle species are attracted to disease-stressed trees. This difference between the redbay ambrosia beetle and other ambrosia beetle species suggests that data from bolts of wood may not transfer to whole trees.
3. The redbay ambrosia beetle is attracted by some yet-unknown signal from host species (e.g., redbay, avocado). The beetle may be attracted to the host species by one or more naturally occurring aromatic volatiles, which are produced by some species in the Lauraceae (Rabaglia et al., 2006). 
4. Redbay ambrosia beetles are more attracted to physically wounded host redbay trees than to non-wounded host trees (Hanula et al., 2008). As a result, pruned avocado trees may be at greater risk of attack from this beetle than are non-pruned trees.

\section{Plant Host Symptoms and Damage}

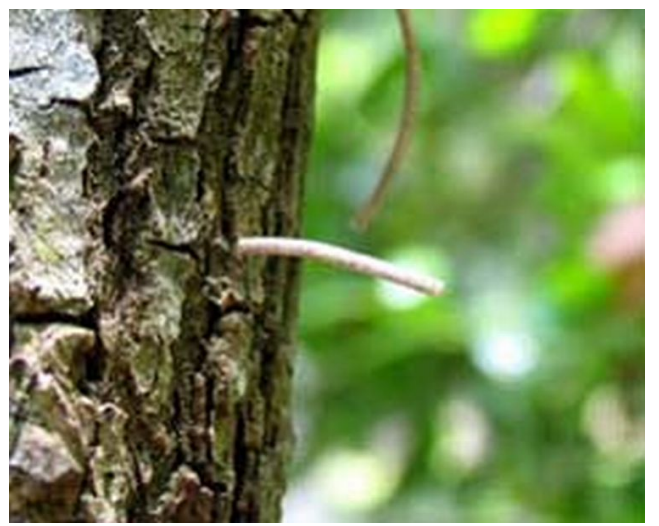

Figure 4. Small strings of compacted sawdust protrude from small bore holes along the trunk of a tree. Credits: Albert Mayfield, Florida Department of Agriculture and Consumer Services

1. Small strings of compacted sawdust (ejected wood fiber) protrude from small bore holes along the tree trunk and limbs (Figure 4). However, these strings of compacted sawdust may not always be present because they disintegrate easily.

2. Removing the tree bark reveals very small bore holes ( $2 \mathrm{~mm}$ in diameter) in the wood at the point of attack from the beetle, as well as dark staining caused by the fungus as it extends into the surrounding, water-conducting tissues (xylem) (Figure 4).

3. Leaf and young stem wilting in sections of the tree show signs of attack (sometimes the entire tree shows signs of attack if the trunk is infested) (Figure 5). Subsequently, leaves in part of the tree canopy or the whole canopy may drop or desiccate and remain attached to the stems.

4. Leaf, stem, and limb dieback; eventual tree death (figures 6 and 7).

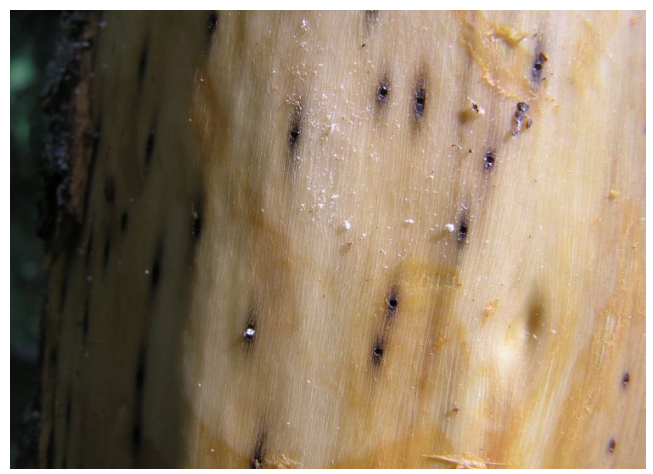

Figure 5. Bore holes are seen when the bark is removed from an infested limb or trunk. Note the dark staining of the sapwood caused by the feeding of the laurel wilt pathogen on the sapwood. Credits: Albert Mayfield, Florida Department of Agriculture and Consumer Services

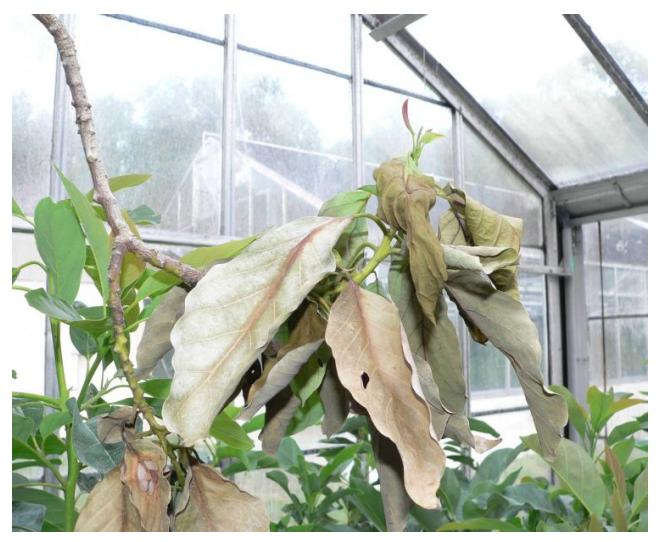

Figure 6. Wilted leaves and young stems of laurel-wilt-infected avocado trees. Credits: Jason Smith, IFAS, Department of Forestry and Conservation, Gainesville, Florida 


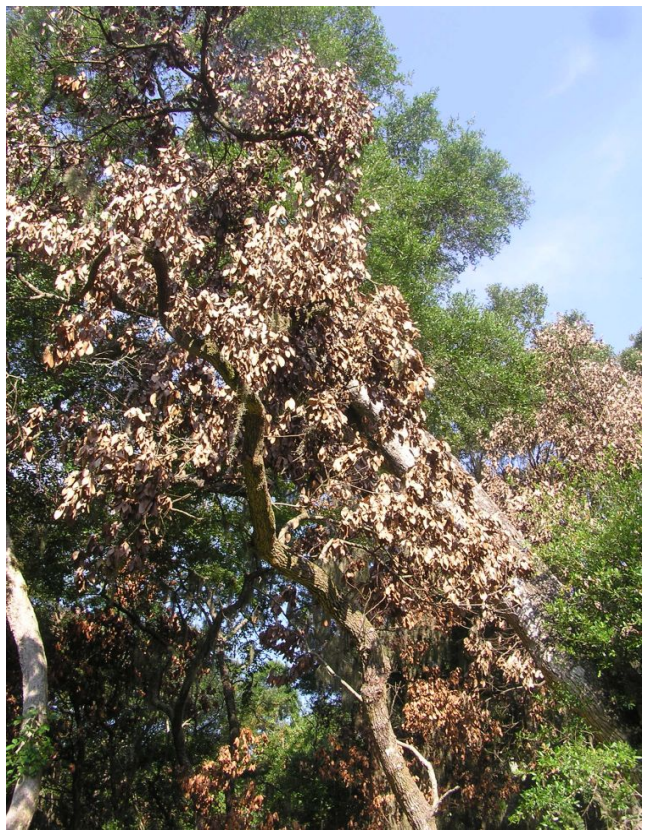

Figure 7. Whole redbay trees killed by redbay ambrosia beetle-laurel wilt pathogen attack. Credits: Albert Mayfield, Florida Department of Agriculture and Consumer Services

\section{Recommended Management Strategies}

\section{(Note: This section will be updated as new information becomes available.)}

1. Rural residents and commercial growers should be on the look-out for signs of rapid wilting, dieback, and insect boring in redbay and other host trees (including avocado) and should report these symptoms to the Division of Plant Industry (http://www.doacs.state.fl.us/pi/index.html or phone 1-888-397-1517) and Division of Forestry (http://www.fl-dof.com/). This information will help regulatory agencies and scientists track the movement of this pest. Preliminarily, redbay ambrosia beetle attacks of redbay appear to be highest from June through October.

2. Redbay and other host woody forest species should not be moved or sold as firewood, tree trimmings, BBQ smoke-wood or mulch.

3. Extreme caution should be used in moving avocado trees and wood products into Miami-Dade County from other counties. Insect-free and disease-free containerized avocado trees should only be purchased from reputable nurseries, and trees showing any signs of wilt or dieback should be destroyed immediately.

4. Avoid plant stress caused by abiotic (non-living) and biotic (living) factors. Usually, ambrosia beetles attack trees suffering from some type of environmental or cultural stress (e.g., drought, flooding, freezing, nutrient deficiencies, etc.). Thus, it is highly recommended to keep your trees as healthy as possible. Optimize strategies for nutrition and water management so to prevent nutrient deficiencies and drought stress. Critical periods to avoid drought stress include when avocado trees are flowering and during fruit development. Periodic irrigation during prolonged drought conditions may be necessary. However, excessive irrigation that results in prolonged soil saturation is also detrimental to avocado trees and may result in phytophthora root rot caused by Phytophthora cinnamomi.

5. Once the beetle and fungus are detected in the commercial avocado production area:

A. Do not move infested trees or tree parts; this may spread the infestation. Burn infested tree parts or trees in the grove to destroy redbay larvae and adults inside the wood (permits may be obtained from your local county or city). Chipping the infested wood will eliminate the wood from being used for breeding beetles. However, because of the very small size of the pest, chipping will not destroy these beetles or larvae. The stumps of dead or dying trees should be burned in-place to prevent further spread of the redbay ambrosia beetle and larvae.

B. Until it is known whether the laurel wilt pathogen can be spread mechanically, consider requiring disinfection of mechanical and hand pruning equipment prior to pruning a grove.

C. Prior to pruning and/or destroying the tree, homeowners should contact their local office of Florida Department of Agriculture and Consumer Services (FDACS), Division of Plant Industry (DPI). Municipalities and counties vary in their regulations concerning the pruning and destruction of trees. 


\section{Chemical Control}

At present there are no registered fungicides for avocado that will control laurel wilt. Preliminary trials protecting redbay trees from laurel wilt by root-flare (at the trunk-root interface) injections with fungicides (i.e., propiconazole) have been successful, but this practice is probably not feasible for commercial avocado groves (Mayfield et al., 2008a). Research continues on determining avocado variety host susceptibility and potential strategies to ameliorate the impact of the laurel wilt disease.

Control of the redbay ambrosia beetle is complicated by various factors. For one, adult beetles must be in the immediate area of aerial sprays to be controlled. Additionally, detection of adult beetles involves monitoring traps and/or scouting groves. Furthermore, once adult beetles bore into the trees, contact insecticides are ineffective.

The current recommendation is to periodically apply permethrin (e.g., Permethrin 3.2 EC or other brands) to the trunk and major limbs, from the base of the tree up to about $10 \mathrm{ft}$ above the ground, beginning in early March. Limbs and branches of trees infested with redbay ambrosia beetles should be removed and burned. Trees that have died (including the trunk) from an infestation should be burned as chipping will not kill developing larvae, which remain as a source of new beetle infestations. Research continues on the question of whether beetle attack differs among cultivars and which repellents and insecticides may control the beetle.

\section{Agencies and Institutions Working on the Redbay Ambrosia Beetle-Laurel Wilt Pathogen}

- United States Department of Agriculture (USDA), Forest Research Service

- Florida Department of Agriculture and Consumer Services (FDACS), Division of Forestry and Division of Plant Industry (DPI)

- University of Florida (UF), School of Forest Resources and Conservation
- UF Institute of Food and Agricultural Sciences (IFAS), Tropical Research and Education Center

- USDA, Animal Plant Health Inspection Service (APHIS) and Plant Protection and Quarantine (PPQ)

\section{Research and Extension Efforts on Avocado}

Research is continuing to evaluate the degree of avocado variety susceptibility to attack by the redbay ambrosia beetle and the extent of damage or death from the laurel wilt pathogen. Work with containerized avocados and avocado plants in the field in infested locations in North Florida is in progress; more is planned. The avocado and fruit-tree nursery industries have been supporting the research effort along with the USDA-Forest Service, Florida Department of Agriculture and Consumer Services, Division of Forestry, and the University of Florida, IFAS.

The commercial avocado industry has been kept abreast of the movement of the beetle and informed of the early results from research on avocado susceptibility to the beetle and fungus. In September of 2008, research and extension faculty of the University of Florida IFAS presented a workshop on the redbay ambrosia beetle-laurel wilt pathogen pest problem for the Avocado Administrative Committee and for local growers. As new information is generated, it will be provided to the industry.

The Florida Department of Agriculture and Consumer Services Division of Plant Industry (http://www.doacs.state.fl.us/pi/index.html) has issued several Pest Alerts to the public concerning this pest problem. An action plan has been developed and is currently being implemented by representatives from the (FDACS) Division of Plant Industry in South Florida, by faculty from UF/IFAS, Tropical Research and Education Center in Homestead, Fla., Miami-Dade Cooperative Extension County faculty, the Miami-Dade County Agricultural Manager, and various members of the Laurel Wilt Working Group. 


\section{What Remains Unknown}

- How attracted redbay ambrosia beetles are to mature (large) avocado trees. Preliminary data suggests larger trees are more susceptible to attack than smaller trees.

- The susceptibility of some avocado varieties to the laurel wilt pathogen.

- Whether the redbay ambrosia beetle can complete its life cycle in avocado trees.

- Whether any beetle repellents have the potential to keep the redbay ambrosia beetle from attacking avocado trees.

- What insecticides are most effective in killing adult redbay ambrosia beetles.

- Whether a trap-and-kill system could be used to control the redbay ambrosia beetle.

- Whether any fungicides that control the laurel wilt pathogen would be cost effective for commercial avocado production.

- Whether the laurel wilt pathogen can be transmitted mechanically by pruning equipment.

\section{More Information and Links}

- Web site of the Laurel Wilt Working Group, hosted by USDA Forest Service, Forest Health Protection, Southern Region: http://www.fs.fed.us/r8/foresthealth/laurelwilt/

- Florida Department of Agriculture and Consumer Services, Division of Plant Industry: http://www.doacs.state.fl.us/pi/

- USDA Forest Service, Forest Health Protection, Southern Region: http://www.fs.fed.us/r8/foresthealth/laurelwilt/ dist_map.shtml

- University of Florida, IFAS, Extension Data Information Source (EDIS): http://edis.ifas.ufl.edu
- Tropical Research and Education Center, University of Florida, IFAS: http://trec.ifas.ufl.edu

- Miami-Dade County Extension Service: http://miami-dade.ifas.ufl.edu/

\section{References and More Information}

Atkinson, T.H. and S.B. Peck. 1994. Annotated checklist of the bark and ambrosia beetles (Coleoptera: Platypodidae and Scolytidae) of tropical southern Florida. Fla. Entomologist 7:313-329.

Bryant, R.M. 2007. Laurel wilt disease or an ecological disaster. Division of Plant Industry, Florida Department of Agriculture and Consumer Services, January 2007. http://www.doacs.state.fl.us/pi/enpp/pathology/ laurel_wilt_disease.html [Accessed 02-4-08].

Fraedrich, S.W., T.C. Harrington, R.J. Rabaglia, M.D. Ulyshen, A.E. Mayfield III, J.L. Hanula, J.M. Eikwort, and D.R. Miller. 2008. A fungal symbiont of the redbay ambrosia beetle causes a lethal wilt in redbay and other Lauraceae in the southeastern United States. Plant Disease 92:215-224.

Gilman, E.F. and D.G. Watson. 2006. Persea borbonia: Redbay, EDIS Publication ENH-595. Envir. Hort. Dept., FL Coop. Extn. Service, IFAS, University of Florida, Gainesville, FL p. 1-3. http://edis.ifas.ufl.edu/ST436 [Accessed 02-4-08].

Hanula, J.L., A.E. Mayfield, S.W. Fraedrich, and R.J. Rabaglia. 2008. Biology and host associations of redbay ambrosia beetle (Coleoptera: Curculionidae: Scholytinae), exotic vector of laurel wilt killing redbay trees in the southeastern United States. Forest Entomology 101:1276-1286.

Harrington, T.C., S.W. Fraedrich, and D.N. Aghayeva. 2008. Raffaelea lauricola, a new ambrosia beetle symbiont and pathogen on the Lauraceae. Mycotaxon 104:399-404.

Mayfield III, A.E. 2007. Laurel wilt: a serious threat to redbay and other related native species. The Palmetto 24:8-11. 
Mayfield III, A.E. 2008. Laurel wilt. Forest and Shade Tree Pests. Fla. Dept. Agri. and Consumer Services, Div. of Forestry. Leaflet 13. p.1-2.

Mayfield III, A.E. and M.C. Thomas. 2006. The redbay ambrosia beetle, Xyleborus glabratus Eichhoff (Scolytinae: Curculionidae). FDACS Div. of Plant Industry, Pest Alert p.1-2.

Mayfield III, A.E., E.L. Barnard, J.A. Smith, S.C. Bernick, J.M. Eickwort, and T.J. Dreaden. 2008a. Effect of propiconazole on laurel wilt disease development in redbay trees and on the pathogen in vitro. Arboriculture and Urban Forestry 34:317-324.

Mayfield III, A.E., J.E. Peña, J.H. Crane, J.A. Smith, C.L. Branch, E.D. Ottoson, and M. Hughes. 2008b. Ability of the redbay ambrosia beetle (Coleoptera: Curculionidae: Scolytinae) to bore into young avocado (Lauraceae) plants and transmit the laurel wilt pathogen (Raffaelea sp.). Florida Entomologist - Scientific Notes 91:485-487.

Mayfield III, A.E., J.A. Smith, M. Hughes, and T.J. Dreaden. 2008c. First report of laurel wilt disease caused by a Raffaelea sp. on avocado in Florida.

Ploetz, R.C. and J.E. Peña. 2007. Laurel wilt: a lethal disease on avocado and other Lauraceous hosts. University of Florida, IFAS, TREC Web site http://trec.ifas.ufl.edu p. 1-6. [Accessed 02-4-08].

Pollack, S. and A. Perez. 2007. Avocado. Fruit and Tree Nuts Situation and Outlook Yearbook. Market and Trade Economics Division, Economic Research Service, U.S. Department of

Agriculture, October 2007, FTS-2007.

Rabaglia, R.J., S.A. Dole, and A.I. Cognato. 2006. Review of American Xyleborina (Coleoptera: Curculionidae: Scolytinae) occurring north of Mexico, with an illustrated key. Annals of the Entomological Soc. of Amer. 99: 1034-1056.

Reid, L., B. Mayfield, and J. Johnson. 2008. Distribution of counties with laurel wilt disease symptoms by year of initial detection. http://www.fs.fed.us/r8/foresthealth/laurelwilt/ dist_map.shtml [Accessed 10-26-08].
Thomas, M.C. 2007. Two Asian ambrosia beetles recently established in Florida (Curculionidae: Scolytinae). Dept. Plant Industry, Florida Department of Agriculture and Consumer Services. http://www.doacs.state.fl.us/pi/enpp/ento/ twonewxyleborines.html [Accessed 02-4-08].

US Forest Service. 2008. http://www.fs.fed.us/database/feis/plants/tree/perbor/ all.html \#DISTRIBUTION\%20AND\%20OCCURRENCE [Accessed 10-25-08].

\section{Acknowledgements}

- Albert E. Mayfield III, Florida Division of Forestry, for information and some photographs used in this publication.

- Jason Smith, assistant professor, University of Florida, IFAS, School of Forest Resources and Conservation, Gainesville, Florida.

- Michael C. Thomas, Florida Department Agriculture and Consumer Services, Division of Plant Industry, for some photographs used in this publication. 